DOI: https://doi.org/10.3126/njdrs.v16i0.31575

\title{
Service Delivery Practices of Local Government in Federal Nepal
}

\author{
Suman Kharel* and Mahesh Tharu** \\ *Faculty member at central Department of Rural Development \\ ** Graduate student of Central Department of Rural Development
}

Email for correspondence: suman.kharel@cdrd.tu.edu.np and maheshchaudhary06@gmail.com

\begin{abstract}
This paper presents effectiveness of service delivery practices of local government in federal context. In doing so, focus was given to analyze opportunities and challenges of administrative service delivery functions of Banganga Municipality of Kapilvastu District located in Province Number 5. This study applied mix method approach in which necessary data are collected from 20 administrative staffs and 100 service receivers selected purposively by applying institutional/exit poll survey, KII, and Observation techniques. The findings reflect the administrative service delivery mechanism becoming more accessible to the citizens. However, physical infrastructure of municipal and ward offices found very poor to offer efficient administrative service delivery to all including people with disabilities. The administrative staffs seem capable for offering efficient administrative service delivery but they are not sufficient. However, the municipality is not institutionally strong in terms of physical facilities. The local representatives also seem more accessible and accountable working with limited physical, economic and human resources. Finally, such challenges must be addressed with proper cooperation and collaboration between and among federation, provincial and local government for making regulatory administrative service delivery functions more effective and efficient.
\end{abstract}

Key words: Local government, administrative service delivery, decentralization, good governance, federalism, federal Nepal

\section{Introduction}

The People's Movement 1990 demolished 30 year's party less Panchayat polity and restored democracy with constitutional monarchy system in Nepal. With the promulgation of Constitution (1990), there was much dissatisfaction which resulted into Maoist's insurgency (1996-2006). The second Peoples' Movement 2005 and the subsequent Comprehensive Peace Accord (CPA) that were taken between government of Nepal and Maoist, provided safe-landing to the Maoist' insurgency. The CPA was signed with a purpose i.e. to write a new constitution of Nepal by representative of citizens in federal model. Historically, election for Constituent Assembly (CA) happened in 2008 though it couldn't give new constitution with sentiment of people movement II and CPA due to confrontational issues of federalism and restructuring state. The second election of the CA held in 2013 and it has provided new constitution on 20th September 2015.

Nepalese Journal of Development and Rural Studies, Volume 16, 2019 
With promulgation of new Constitution of Nepal (2015) has ensured sovereignty of people in the federal structure. Constitutionally, there are three-level of governments in Nepal. Federal government is at center, state government is at the provincial level and local government is at below. In this structure, power/jurisdictions are devolved to the federation, provincial and local governments based on the principle of cooperation, co-existence and coordination (LBMB, 2015). All together, there are 753 local governments including Metropolitan city, Sub-metropolitan city, Municipality and Rural Municipality (Election Commission of Nepal, 2017). The legislative power has been vested to Village Assembly and Municipal Assembly provisioned in schedule- 8 of the new Constitution of Nepal (2015). The local levels have a wide range of authority ranging from participatory plan formulation process to managing effective administrative service delivery ${ }^{1}$. It means, by constitution the local levels have been made powerful i.e. effective/optimum decentralization in the federal context of Nepal. It has been done to make service delivery more public oriented. Furthermore, the government has been trying to serve the public from their door in terms of effective administrative service delivery, planning and implementation of development activities with participation of people creating ownership in the mind set of locals. To the end local governments are implementing 22 devolved power/jurisdictions that are an outcome of decentralization process practicing now to then.

\section{Historical Development of Local Government}

Local government before 1950s. During tenure of Kirant, there were Thum, and Panchali as form of local government. Panchali served as the lowest local body and Thum served as Ilaka level local body. Elected person by locals called Paantimyanga was regarded as chairperson of the local bodies. Likewise, during Litchhabi tenure, there were Gram, Tal and Dranka local bodies. We can related to Gram as village level, Tal as communal unit of villages and Drank was as for high populated area' governing unit. Similarly, in Malla ruling tenure, there were three categorized local units - Bhukti, Bishaya and Gramkeshtra. There was provision of Panchali and Panchaasamuchchaa as for local development and justice. The members for these bodies were appointed from Centre.

Local government after 1950s. With establishment of democracy in Nepal 1950 abolishing Rana regime, local Panchayat was established as local body. During 1950-1960, Gram Panchayat Block and Tribhuvan Gram Bikas Samiti were established and developed as local bodies in Nepal.

In 1961 King Mahendera structured to Nepal into 14 zones, and 75 districts. With promulgation of Panchayati system in Nepal the king Mahendera Shah enforced ordinance demolishing the previous Gadi, Gauda and Goshwara and provisioned District, City and Village Panchayat for development and administration. This was proved that it is milestone for decentralization and local governance in Nepal. During the Panchayat polity the government led by Krishna Prasad Bhattarai declared VDC, Municipality and DDC Act 1971. The Panchyat political system ran till 1990. People Movement 1990 re-established multiparty democracy with constitutional monarchy in Nepal.

After the promulgation of new constitution 1990, the local bodies namely- District Development Committee (DDCs), Village Development Committees (VDCs) and Municipality were established under separate DDC, VDC and municipality Act adopted in 1991. Local Self Governance Act, 1999 and its Regulation, 2000 provided comprehensive and integrated legislative platform for

1 The researchers used this term to denote those local level services which are related to vital registration and registration, recommendation and verification of documents.

Nepalese Journal of Development and Rural Studies, Volume 16, 2019 
the local government for marching more autonomous local bodies with capacity to mobilize financial resources and human resource management in their own way. Despite these initiatives and practice, the local governments were undermined by the armed conflict (1996-2006) between the Government and Maoist insurgents in 2000s (World Bank, 2014). The constitution has restructured Nepal in essence of federalism into 7 provinces and 753 local levels including municipality and rural municipality.

Federalism. Federalism refers to the multi-tiered governments combining elements of 'shared rules' ${ }^{2}$, and sate 'self- rule" ${ }^{3}$. Within the genus of federal political system, federalism represents a particular species in which neither the federal nor the constituent units of government are constitutionally subordinate to the others. It means each federal state has sovereign power derived from the rather than another level of government, each is empowered to deal directly within its citizens in the exercise of its legislative, executive and taxing power and each is directly elected by citizens. Historically, the issues of federalism date back to 1950 in Nepal whereby regionalist movement was witnessed. The crusade was led by Nepal Tarai Congress postulating Tarai as autonomous state, Hindi as administrative language and ensuring more jobs for Madheses people in government. Despite the substantial efforts, the idea faded out soon after. With restoration of democracy in 1990 and the establishment of parliamentary democracy opened the door for addressing aspirations and expectation of ethnic demand, acknowledging ethnic nationalities and their sociocultural diversity.

In 1990 umbrella organization of ethnic named Nepal Federation of Nationalities and rather politically, the Rashtriya Janamukti Party and the Nepal Sadbhavana Party, both were advocating a federal Nepal, contested the general elections in 1991, 1994 and 1999. The Maoist's insurgency raised identity politics demanding identity, power sharing, regional autonomy of backward areas and optimum decentralization. With people's movement II 2005 and CPA, Interim Constitution of Nepal 2007 was promulgated. Madhesh movement also happened demanding federalism and proportional inclusion in governing system and government jobs. Finally, the federalism was accepted by Interim Constitution of Nepal $2007^{4}$. However, the understanding about federalism in Nepal was contested. Some political parties including CPN Maoist took the federalism as the resolution of discrimination, and inequality caused by unitary and centralized system. Similarly, Nepali Congress, CPN UML took the federalism as popular demand of time (Karki, 2014).

In this background this study tried to analyze effectiveness of public service delivery practices of Banganga Muncipality, Kapilvastu district. It is fact that when the local levels come with full-fledged in term of physical resources and human resources, the public can get qualified and quantified service. Such kind of effective and efficient service delivery directly provide opportunity to the public to invest their valuable time in productive sectors. Similarly, it can create a kind of faith among the public towards the local government and its modality.

\section{Objectives}

- To look at on institutional capacity of Banganga Municipality.

- To analyse the effectiveness of administrative service delivery practices of the Municipality.

- To appraise the existing opportunities and challenges facing by Banganga Municipality.

2 Constitution of federal government constitutes to all provinces.

3 Laws made for particular state government.

4 Federalism was accepted by 4th amendment of Interim Constitution of Nepal 2009 for addressing Madhesh Movement.

Nepalese Journal of Development and Rural Studies, Volume 16, 2019 


\section{Methods and Materials}

This study applied both quantitative and qualitative methods as philosophical ethic is going towards mix method approach and validity corroborate data (Creswell \& Plano Clark, 2010). In doing so, two types of research questions (qualitative and quantitative) have been used and two types of data (numerical and narrative) have been collected according to research issue (Tashakkori \& Teddlie, 2003). The primary data both numerical and narrative are collected through institutional survey, exit poll survey, KII and observation techniques. Similarly, the secondary data are collected through published/unpublished books, report and documents (i.e ordinance, Acts, Laws and Bulletins). The researchers purposively selected 4 ward offices and office of the Banganga Municipality by applying accidental sampling method. More specifically, institutional survey is conducted with 20 administrative staffs working in five offices and Exit Poll survey was conducted with 20 service receivers from all the five offices (4 word office and office of the Municipality).

\section{Study Area at a Glance}

Banganga Muncipality is located in Kapilvastu District in Province no. 5. Kapilvastu covers $1,738 \mathrm{~km}^{2}$ of Nepal's Western Region situated in Lumbini Zone. Its elevation ranges from 90 to 824 meters above sea level and it is $48 \mathrm{~km}$ long and $34 \mathrm{~km}$ wide (CBS, 2012). Kapilvastu comprises 10 local levels including 5 RMs and 5 Municipalities with its District Headquarters (DHQ) in Taulihawa (Election Commission of Nepal, 2017). Banganga Municipality is established in 2015 assimilating to all together seven VDCs (Figure 1). The municipal office is located at Gajehada being center of the municipal area. The majority of population living in this municipality is Tharu community which comprises 37.16 percent of total population of the municipality. Following this, other dominant caste/ethnic groups include;

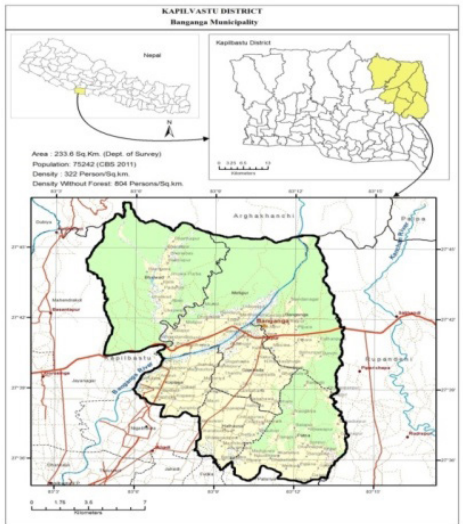

Figure 4. Map of Study Area Brahmin -hill (25.08\%), Chhetri (9.60\%), Magar (17.6) in the municipality (CBS, 2012).

\section{Discussion of Findings: Human Resources of the Municipality}

Profile of administrative staffs. The municipality has all together 60 staffs ranging from administrative chief to office assistant. Among them, 16 staffs are newly appointed under the official's assimilation mechanism of government of Nepal. To assess the institutional capacity, educational status, working experience and trainings of the administrative staffs have been assessed. Working experience was evaluated considering the inner capability of governmental officials for efficient service delivery. Out of 20, 75 percent of the civil servants attained higher education degree. Working experience reflects that there was more staffs were newly joined into the municipality job. Out of 20 staffs, 10 staffs had working experience ranging between 1-3 years. Majority of the staffs i.e. 50 percent staffs got training ranging between 1-3 years. It is followed with 40 percent of the staffs. Only two staffs had had more experience ranging between 7-10 years. It is taken as the surest and most effective strategic instrument 
for correcting deficiencies for meliorating service delivery as the well trained staffs can serve the most effective way in qualitative and quantitative terms.

Profile of elected representatives. The elected representatives are cardinal agent for implementing national legislative policies and directives. They are, in addition equally prudent so as to formulate effective policies for development and deliver administrative services to people. Leadership is charismatic itself which is emerged/developed not with academic knowledge rather by virtue and strong will power. There by, education and occupational status of the elected representatives really matters with institutional capacity. In this regard, out of 40 cases, 11 representatives got education up to secondary level. It is followed with 8 representatives having educational attainment up to basic level. It is misfortune to be found only 2 representatives attaining higher academic degrees at governing level though higher academic degree and space of development don't have direct correlation. Likewise, out of 40 cases, 37.5 percent elected representatives responded that they involved in political activities beside other activities. Following this, 32.5 percent representatives came from farming background as farmers. Likewise, the 17.5 percent representative occupied positions in local government who were from entrepreneurship sectors. 12.5 percent representative involved in different N/NGOs.

Physical resources of the municipality. The availability of physical infrastructure is the basic foundation of any organization. Hence, for the study, for the good governance, there should be sufficient foundation of constitutional provision, human resources and physical resources. To assess the physical resources, variables like communication facilities and computer system have been accessed. This study found that out of 100 service receivers, 63 service receivers responded that there was connection of communication facilities like internet but it was not sufficient. Only 32 service receivers responded that there was sufficient communication facility. Following this only 5 service receivers noticed the communication facility and responded that there was adequate communication facility for administrative service delivery. The 45 service receivers responded that there is installment of computer system but it was insufficient for delivery services. Following this 48 were satisfied and responded that it was sufficient for casting administrative services. And only 5 service receivers responded that computer system installments in the studied area were adequate for administrative service.

\section{Effectiveness of Administrative Service Delivery of Municipality}

Awareness of service receivers. As the argument of right based approach of development, the justifiable development will be there where there are active service receivers who always make cautious to service providers. The researchers used to measure awareness level of the service receivers using the follow up of the citizen charter board. The study found that out 100 only 8 respondents were aware about the citizen charter board. Due to lack of citizen charter board in people did not pay heed for that. Consequently, out of 5 studied offices, only 2 offices had citizen charter board in their primes. Furthermore, due to such trend, no any service receiver follow any schedule rather come directly to secretary for consultation as well as perform task with him/her.

Frequency of visiting ward offices and municipal office. Frequency of visiting subordinate office of municipality has been considered as one of the best variable to assess the effectiveness of administrative service delivery. It is argued that if there is effective administrative service delivery, the service receivers doesn't repeatedly visit the office of municipality/ward for the same purpose. In this line, it is found that about half of the total i.e. 54 percent service receivers visited only one time for the 
same service. Following this, 35 percent service receivers visited two times for the similar administrative task. Likewise, 11 percent service receivers visited three times for the same administrative service. The researchers further tried to go in depth for finding out what kinds of reasons were there for delay in administrative service delivery. Most of the service receivers who visited the ward offices two times or more than two times, responded that they didn't have sufficient knowledge for required documents, so we got delay in administrative service delivery. Absenteeism of chair of ward office was also one of the reasons for delay administrative service. 42 year old male respondent said that:

Before, local election, the administrative service was performed only by the ward secretary, it was fast. Now we need to signature of ward chair. And the ward chair's frequent absent in the office due to their regular meeting in municipality and DCC, we fall in problem. We have to go home of the chairperson for their sign. Therefore, we were not benefited. We have to come two times or have to go to home of the chair for only sign of them (Based on the personal conversation of the researchers with the research participant on 9th October, 2017).

This is a vibrating response of the service receiver regarding to service delivery mechanism. This kind of problem questions to the public service delivery about its effectiveness. If such trend gets high, the aspirations and expectations of the people never comes into reality. And then there will be no any distinctive difference between unitary model and federal model. Therefore, the newly elected representatives need to stop such kind of problem faced by few people.

Process to get a service. The procedure is also a variable for assessing effectiveness of administrative delivery in the municipality. When there is short and sweet administrative procedure for getting service, it directly accelerates to effective administrative service delivery. Generally, there are two steps followed for getting administrative service. Hence, the researchers inquired regarding to steps followed to get a service, following findings are found. The findings show that most 56 percent service receivers followed two steps. Following this, 37 percent service receivers followed three steps for getting a service. Likewise, only 4 percent service receivers followed the one step and 3 percent service receivers followed four steps for getting administrative service. The researchers again inquired with the service receivers what kind of steps they need to be followed. It was found that most of the service receivers came to ward office with application letter; they had to pass two steps i.e. preparation administrative task like preparation of recommendation letter from secretary and verification with chair of the ward office. Those who didn't come with application letter, they needed to follow three or four steps. One steps followed was exception since, the ward secretary did all things in presence of the chair person.

Time for getting service. With the restructuring local government many more administrative services have been vested to the local levels. It means the administrative service delivery is going to be more accessible. The researchers also tried to explain information about consuming time for getting an administrative service. In this attempt, most 60 percent service receivers got their administrative service within half days. Following this, 29 percent of the service receivers got their administrative service within one day. 10 percent of the service receivers got their service within two days. Likewise, there was only 1 percent of the service receivers got their service on more than two days. Most of the tasks were related to ward offices. So, they got service within half days. The municipal office is located at the centre of the municipality. So it took a day generally to get administrative service. The executive 
officer of the municipality told that the whole staffs of the municipality were devoted to efficient service delivery to serve people to internalize the essence of federalism but those service receivers who hadn't required document, they bound to come to the office more than two times.

Status of computerized service delivery. The governing system of Nepal is going to be transformed into e-governance. The paper based service delivery has been changing into digitalized system for making the service delivery effective, efficient and transparent. Out of 100, only 30 service receivers got the administrative service delivery through computer system as only two ward offices were provided computerized services to the service receivers. The computer system was not installed at the ward office for making receipt of payment. As per nature of administrative service, 38 service receivers came to ward/municipal offices for getting recommendation letter. Among them, 10 service receivers got computerized recommendation letters for further process. Similarly, 22 service receivers visited offices of the municipality for getting verification of documents. They got service through computer system. Likewise, 7 service receivers out of 40 who visited offices of the municipality got service through computer system. 30 service receivers who visited for getting registration and verification paid fees and got computerized receipt bill.

\section{Opportunities for Administrative Service Delivery}

Access to administrative service. The accessibility of service delivery in local level is one of the major opportunities for administrative service delivery. Principally, the local government is aimed to be established as close as possible with local people. The LSGA, 1999 and Regulation, 2000 also provided administrative service relating to the vital registration. But the LGOA, 2017 has enlisted 22 power/jurisdictions relating to administrative service delivery. This provision obviously saved both time and money of the service receivers. It is opportunity for the local people to get service at their door. It creates multiplier effect for transformation of rural life. The local people can get their service within their separate time saving both money and time. They can invest their time/money in productive sectors which assist directly to uplift their economic condition.

Administrative convenience. The term administrative convenience is a broad which covers to digitalized service delivery, availability of waiting room for service receivers, compensation based citizen charter board, etc. The administrative convenience is directly associated with hiking result oriented public service delivery. The service delivery mechanism is much more convenient in comparison to previous practice as the optimum power devolution to local levels. Besides these new provisions of administrative services to local levels, the municipality has been considered as comfortable service centre since it is aimed to render services to citizen in very promptly. Therefore, with federal polity, the government has already initiated e-governance in Nepal. In the same theme, one of the chairpersons of a ward office expressed that:

We are servant of local people not representatives. The government has provided different roles and functions which are for serving local people. So, when we go receivers' to meeting due our district level meeting and municipality level, the service administrative service cannot be completed. Therefore, I requested a member of ward to come to the ward office and perform task honestly (Based on the personal conservation of the researchers with research participant on 6th October, 2017). 
The above narrations proved that implementation and operationalization of the opportunities are determined by the locally elected representatives. When they do have willing power to make administrative more convenience and comfortable, they can it easily. Hence, constitutionally, the local government in federal context has opportunity of administrative convenience.

\section{Challenges for Administrative Service Delivery}

The federalism is a broad governing system. It demands optimum level of decentralization at local levels. The optimum levels of decentralization in all dimension, requires to sufficient infrastructure, availability of efficient human resources, required economic sources. Such perquisites of the federal governing system only accelerate and ensure the effective service delivery. Hence, this study highlighted poor physical infrastructure, financial and human resources related challenges of local government in general and Banganga Municipality in particular.

Poor physical infrastructure. The weak physical infrastructures both external and internal were challenging to the municipality for effective administrative service delivery. The researchers found that the municipality has not proper physical infrastructure for offering administrative service delivery functions. The four ward offices had their own buildings but those building were not sufficient to provide service in section wise. One ward office was damaged during Maoist's insurgency. And due to lack of internal economic source, it couldn't be maintained. Further, a joint ward office has been operating for providing public services to the citizens. Even the newly constructed municipal office has not sufficient building infrastructure to offer administrative service delivery effectively and efficiently. All the offices are not friendly for people with disabilities.

Likewise, the required physical resources like communication facilities, alternative power backup, and Internet were also not available at the ward office. The mayor of the municipality responded that first challenge and problem of the municipality is the unavailability of the physical infrastructure including building for the office. The constitution has provided many functions and to make systematic and standard service delivery, Regarding to this, a ward chairperson shared that:

During the Maoist's insurgency, the building of contemporary VDC was damaged. The ceiling is totally damaged. During this monsoon, the rainfall water was leaked through the ceiling. It was very difficult to be seat there. And then how we can perform under this situation (Based on the personal conversation of the researchers with research participant on 25 October, 2017).

Hence, the physical resources directly or indirectly plays vital role for making administrative service delivery effective and efficient. The human resources were capable but they had not required tools, equipment and other facilities at ward/municipal offices. After then, how they can provide quality service to the service receivers. Therefore, unavailability of the physical resources and infrastructure is one of the challenging factors to the effective administrative service delivery of the municipality.

Financial resources. Offering administrative service delivery to the citizens more effectively and efficiently is almost impossible without sufficient economic resources. According to Constitution of Nepal (2015), the federation has provided equalization grant, counterpart grant, special grant and conditional grant to the local government. The equalization grant is not for making administrative service delivery effective as provisioned in prevision grant allocation mechanism. It means, to maintain the economic capital, source of local revenue is major. At the initial period, the local government couldn't enlarge the coverage of tax as its target due to legal problems since many functions related 
to tax collection are guided by law of province. However, in the municipality, the major economic resources were local market, river related resources, forest related resources, micro level industries like rice mill, furniture, etc. There were not big industries. It means coverage of revenue is limited. It results low collection of revenue. It directly affects to the municipality in terms of providing effective service delivery.

Sufficient human resources. Human resource is the most important resources out of the other since it mobilizes to other rest resources. There are not sufficient human resources in local level for proper implementation of devolved power/jurisdictions. This study also found that there was a problem of human resources for making effective and efficient administrative service delivery mechanism. A single Ward Secretary has been performing the administrative functions of the service receivers of two wards. Such incident was found in two ward offices whereby joint ward office was there. It means the secretary had double pressure of administrative functions. According to Local Level Operation Ordinance 2017, in a ward office, there are at least three public officials namely, Ward Secretary, Administration and Assistant Accountant and Office Assistant. Regarding to this provision, the researchers didn't found that structure of human resource rather, there were Ward Secretary, Social Mobilizer and Office Assistant. The social mobilizes were under the LGCDP budget scheme. Similarly, due to problem of human resource the recommendation letter in English medium was not provided from the ward office. The researchers further inquired with mayor and executive officer of the municipality regarding to this human resources availability. The mayor responded that they have not sufficient staffs hence planning to appoint new administrative staffs themselves.

\section{Conclusion}

The newly restructured municipality in federal polity has opened the door for effective administrative service delivery in local levels. The administrative service delivery mechanism becoming more accessible and efficient to the citizens. The administrative staffs seem capable for offering efficient administrative service delivery but they are not sufficient. However, the municipality is not institutionally strong in terms of physical facilities. The building of ward office and municipal office was not sufficient and not friendly for people with disabilities. Besides, local representatives are not well trained and well-informed about 22 devolved power/jurisdictions but seem more accessible and accountable. They are fulfilling their duty and responsibility even with limited physical, economic and human resources. Such challenges must be addressed with proper cooperation and collaboration between and among federation, provincial and local government.

\section{References}

Adhikari, R. (2010). Local governance institution in Nepal: Status and challenges. Retrieved from http:// www.academia.edu/1831963/Local_Government_Institutions_in_Nepal_Status_and_Challenges

Agrawal, G. R. (2015). Dynamics of human resource development in Nepal (6 ${ }^{\text {th }}$ ed.). Kathmandu: M. K. Publishers and Distributer.

Atkinson, D. (2002). Local government, local governance and sustainable development: Getting the parameters rights. Cape Town: Human social science council, Cape Town, South Africa. Retrieved from http://seg.fsu.edu/Library/Local_Government,\%20_Local_Governance_and_ Sustainable_Development_Local_Government,\%20_Local_Governance_and_Sustainable_ Development_-_Entire_eBook.pdf

Nepalese Journal of Development and Rural Studies, Volume 16, 2019 
Central Bureau of Statistics (CBS). (2014). National population and housing census 2011(Volume 06). Kathmandu: CBS, Government of Nepal.

Creswell, J. W., \& Plano Clark, V. L. (2010). Designing and conducting mixed methods research. Thousand Oaks, CA: Sage.

Dhungel, R. (2004). Decentralized governance: A perspective for Nepal. Paper presented at Indian Institute of Management, India.

Election Commission of Nepal. (2017). Local election [Bulletin]. Kathmandu: Author.

Gamper, A. (n. d.). A global theory of federalism: A nature and challenges of federal state. German Law Journal, 6(10), 1297-1318. Retrieved from https://static1.squarespace.com/ static/56330ad3e4b0733dcc0c8495/t/57634f3e893fc07fb7eebfcd/1466126143493/GLJ Vol_6_No_10_Gamper.pdf

Government of Nepal (GoN). (1999). Local self governance act 1999. (1999, December 30). Retrieved from http://www.mofald.gov.np/sites/default/files/Resources/docs_25.pdf

Government of Nepal (GoN). (1999).Local self governance act 1999. (1999, April 29). Retrieved from http://www.mofald.gov.np/en/node/137

Gurung, N. (2011). Local democracy in political transition of Nepal (Discussion Paper No. 1). Kathmandu: SIAS and ASD. Retrieved from http://asd.org.np/publications/local-democracypolitical-transition-nepal

Huberman, A. M., \& Miles, M. B. (1998). Data management and analysis methods. London: Sage Publication Inc.

Karki, B. (2014). State restructuring and federalism discourse in Nepal. In Karti, B. \& Edrisinha, R. (Ed.). The federalism debate in Nepal. (1-22). Kathmandu: UNDP, Nepal and SPCBN, Nepal.

Khan, N., Kundi, M., Shah, B., Khan, A., \& Kamal, B. (2012). Prospect of new local government system: An empirical study of local government in district Dera Ismail Khan. Journal of Public Administration and Policy Research, 4(2), 42-49. DOI: 10.5897/JPAPR10.020

Lamichhane, H. R. (2012). Fiscal federalism and local government finance in Nepal. (M. Phil's thesis, Central Department of Economics, Tribuvan University). Retrieved from http://www. addcn.org.np/publication_pdfdoc/Fiscal_Federalism\%20and\%20Local\%20Government Finance\%20in\%20Nepal-Hem\%20Raj\%20Lamichhane_March\%2020121.pdf

Law Books Management (2007). Interim constitution of Nepal 2007. Kathmandu: Author.

Law Books Management Board (2015). Constitution of Nepal. Kathmandu: Author.

Ministry of Federal Affairs and Local Development (MoFALD). (2017). Local government operation act 2017. (2017, October 15). Retrieved from http://www.mofald.gov.np/en/node/2738

Ministry of Federal Affairs and Local Development (MoFALD). (2017). Local level service operation and management ordinance 2017. (2017, May 16). Retrieved from http://www.mofald.gov. np/en/node/2270

National Association of Village Development Committee in Nepal (2014). Federalism and local selfgovernance. Kathmandu:Author.

Olsen, H. B. (2007). Decentralization and local governance: Definitions and practice. Retrieved from https://www.eda.admin.ch/content/dam/deza/en/documents/publikationen/Diverses/167288decentralisation-local-governance_ENpdf. 
Pant, P. R. (2012). Social science research and thesis writing (6th ed.). Kathmandu: Budha Academic Publishers and Distributer Pvt. Ltd.

Pieterse, J. N. (2010). Development theory. New Delhi: Sage Publications India Pvt. Ltd.

Pokharel, B. (2004). Rural political economy of Nepal. Kathmandu: New Hira Books Enterprises.

Pradeep, H. U. S. (2011). Challenges of local government service delivery: A case study of Matara Municipal Council. (Master's thesis, General and Continuing Education Department, South North University Bangladesh).

Sanyal, D. (2017, March 15). Transitional challenges of local body restructuring. Nepal Khabar.Com. Retrieved from http://nepalekhabar.com/2017/03/74440

Sapkota, M., \& Tharu, M. (2016). Development a contested discourse: An overview. Nepalese Journal of Development and Rural Studies, 13(1), 13-28.

Shah, A. (Ed.). (2006). Local governance in developing countries. Washington D.C.: World Bank Group.

Shah, R. K. (2017). Fiscal federalism in Nepal. Kathmandu: Ekta Books.

Sharma, P. (2015). Accountable mechanism promoting grassroots good governance. Nepalese Journal of Development and Rural Studies, 12(1\&2), 113-155.

Shrestha, T. N. (2000). The concepts of local government and decentralization (Reprint). Kathmandu: Ratna Pustak Bhandar.

Sik, T. D. (2001). Democracy at local level. Halmstad: Bulls Trycken, Halmstad, Sweden.

Tashakkori, A., \& Teddlie, C. (Eds.) (2003). Handbook of mix methods in the social and behavioral sciences. Thousand Oak, CA: Sage.

World Bank. (WB). (2014). Local service delivery in Nepal (Repot No. 87922). Retrieved from http:// documents.worldbank.org/curated/en/188401468053415165/pdf/879220ESW0REVI003852 28B00PUBLIC00NP.pdf 